\title{
Three phase PUC5 inverter fed induction motor for renewable energy applications
}

\author{
G. V. V. Nagaraju ${ }^{1}$, G. Sambasiva Rao ${ }^{2}$ \\ ${ }^{1}$ Department of Electrical and Electronics Engineering, Acharya Nagarjuna University, India \\ ${ }^{2}$ Department of Electrical and Electronics Engineering, RVR \& JC College of Engineering, India
}

\begin{tabular}{l} 
Article Info \\
\hline Article history: \\
Received Jul 17, 2019 \\
Revised Sept 9, 2019 \\
Accepted Oct 25, 2019 \\
\hline Keywords: \\
CHB \\
NPC \\
Power Quality \\
PUC5 \\
Sensor less voltage balancing \\
Multievel Inverter \\
Single DC Source
\end{tabular}

\begin{abstract}
This paper gives the overview three phase 5 level packed U cell (PUC5) inverter fed Induction Motor feed from renewable energy sources for electric vehicles and water pump set in agriculture applications. PUC5 inverter requires a minimum number of semiconductor devices, one PV panel and only one capacitor in each phase. Maximum all possible switching sequences are analyzed and sensor less voltage balancing technique depending on simple switching modes was integrated as level shifted PWM controller for control the PUC5 inverter switches. Sensor less voltage balancing fixes the capacitor voltage $(\mathrm{Vc})$ at half of the PV source (Vdc) magnitude in each phase, which results the symmetric five level wave in phase voltage output and seven level waveform in line voltage with less harmonics. This topology minimizes the complication in the control system which creates the PUC5 inverter most suitable for industrial applications and market requirements. It is compared with other popular multilevel inverters In terms of component count, voltage rating, voltage balancing and complexity etc. In order to test the performance proposed PUC inverter it is tested with rated load with Matlab/Simulink. The results obtained have shown good dynamic performance under different conditions.
\end{abstract}

This is an open access article under the CC BY-SA license.

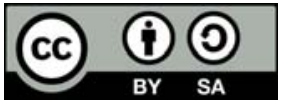

\section{Corresponding Author:}

V V Nagaraju Goriparthi,

Department of Electrical and Electronics Engineering,

Acharya Nagarjuna University, Guntur, India.

Email: nagaraju006@gmail.com

\section{INTRODUCTION}

The world power demand in the energy market leads to redesign of power converters. The power conversion quality is broadly divided into two categories. The first converters inject pollution into the system in term of power factor and harmonics, researchers are trying to enhance the power quality by using filters. Generally, this reduces the efficiency of power conversion and increase cost of installations. The main aim of the second one is to deliver a less cost, high energy efficient inverter without pollution, multilevel inverters belongs to this category [1]. The multilevel inverters role has been increasing in medium and high power applications in the power market, because of advantages, like their capacity to synthesize a waveform with more number of levels, better voltage profile, reduced switching stresses, minimized output filter size. Multilevel found the solution to extend the inverter operating voltage higher than the voltage limit of semiconductor devices [2]. NPC topology was first proposed by Nabae and Takahashi in 1981. Ten years later flying capacitor converter topology was introduced by Meynard and Foch, in this converter the two clamping diodes of NPC was replaced by capacitors [3]. Implicated cell multilevel topology has been explained in1993 and H-bridge cells in 1996. Which connect several inverters in cascade connection with 
separate DC sources. This converter can avoid clamping diodes or voltage balancing capacitors. During these years, several optimizations were proposed by researchers and showed very good performance, such as a large number of levels with with improved output waveforms, low total harmonic distortion and improved efficiency [4-6].

All these topologies have been introduced for multilevel converters that utilized the combination of active switches and DC sources to generate multilevel waveform at the output $[7,8]$. The major challenges of these multilevel inverters are usage of more number of isolated DC sources and too many numbers of switching devices, these problems are eliminated in PUC converter which is invented by Al-Hadded in 2010 and several papers are published by Al-Haddad and Hani vahedi on the PUC inverter with R and RL loads [9]. This paper proposes a three phase five level PUC inverter fed induction motor feed from the PV source through DC/DC converter, compared all popular multilevel topologies and simulate the test system using Matlab/Simulink. This topology is interesting in hybrid electric vehicles and agriculture pump sets by utilizing solar and wind energy [10-12]. Five level PUC inverter is established as a solution to the seven level PUC inverter issues. Switching modes of PUC5 converter are controlled by sensor less voltage balancing techniques, this technique is recommended because of simple design and does not require any sensor, which increase the reliability of the system and full fill the industrial requirements.

\section{PUC5 CONVERTER}

Three phase PUC5 inverter fed induction motor is shown in Figure 1. It consists of four low voltage switches two high voltage switches in each phase. A $1.8 \mathrm{~kW}$ PV array connected to each phase of three phase PUC5 inverter at $\mathrm{V}_{\mathrm{DC}}$ through DC/DC boost converter. The PV array uses six sun modules (SRP-305EWHT-D) in each phase. Total 18 modules $(6 * 3 * 305=5.49 \mathrm{~kW})$ with open circuit voltage of $64.2 \mathrm{~V}$ and short circuit current of 5.96A at $1000 \mathrm{w} / \mathrm{m}^{2}$ sun irradiance and $25^{\circ} \mathrm{C}$ ambient temperature [13-15]. The DC/DC converter uses incremental conductance and integral regulator MPPT technique is used to extract maximum power from the panel under irregular weather conditions. Boost converter boosts the voltage to $440 \mathrm{~V}$ and connected to PUC5 inverter at $\mathrm{V}_{\mathrm{DC}}$. If this $\mathrm{V}_{\mathrm{DC}}$ is $2 \mathrm{E}$ volts, then another source $\mathrm{V}_{\mathrm{C}}$ must be $\mathrm{E}$ volts [16]. Previously published papers on 7 level PUC inverter with different modulation techniques show some limitations with voltage balancing procedure in terms of modulation index [17]. These limitations are eliminated in sensor less voltage balancing technique and do not require sensors or controllers to maintain required voltage across capacitor $\mathrm{V}_{\mathrm{C}}[18,19]$. In the design consideration power industry use identical devices in the multilevel inverters. It is difficult to have equal voltage range switches. But PUC converter shown in Figure 2(a), has a voltage of $2 \mathrm{E}$ volts across S1, S3 and remaining all switches subjected to E volts, by adding two identical switches in series in the S1, S2 of inverter it could be designed with identical voltage rating switches as shown in Figure 2(b). Another design consideration about switches S4, S5 and S6 are working complementary to S1, S2 and S3, So three main pulses devise S1, S2 and S3 while their NOT sent to S4, S5 and S6 [20].

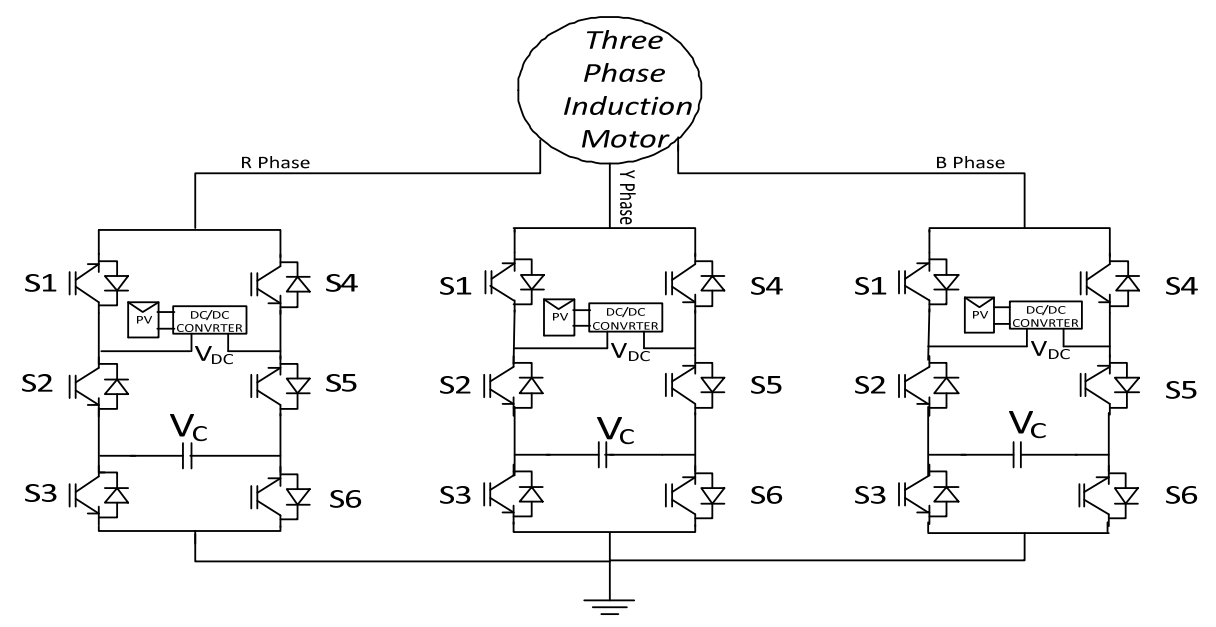

Figure 1. Three phase PUC inverter fed induction motor

Int J Pow Elec \& Dri Syst Vol. 11, No. 1, Mar 2020 : 1 - 9 


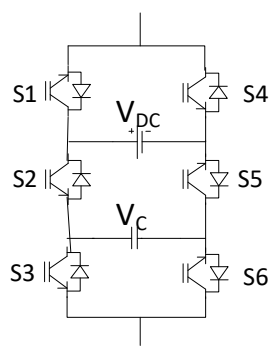

(a)

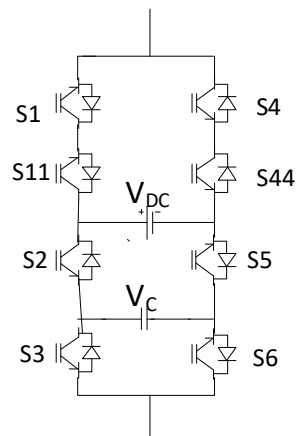

(b)

Figure 2. PUC5 inverter with (a) unequal voltage rating switches (b) equal voltage rating switches

\section{SENSOR-LESS VOLTAGE REGULATING TECHNIQUE}

Table 1 shows that the capacitor may be charged or discharged in any one half cycle. Only to maintain the capacitor voltage constant the switching sequence of the capacitor is designed in such a way that it should be discharged in the negative half cycle and charged during the positive half cycle. Because of the switching sequence of capacitor and output waveform frequency the capacitor charge is increased to half of the main source voltage $\left(\mathrm{V}_{\mathrm{dc}}\right)$. As a result this capacitor voltage $\left(\mathrm{V}_{\mathrm{C}}\right)$ increases when it is connected in series with the load and $V_{\mathrm{dc}}$ source, decreases when it is connected in series with the load. The capacitor charges in switching states 2 and 7 , similarly capacitor discharge in switching states 3 and 6 . The capacitor voltage $\left(V_{C}\right)$ during charge/discharge is $\pm \mathrm{E}$ volts as shown in Table 1. This charging and discharging is written into the equation (1).

$$
V_{1}=V_{2}+V_{\text {out }} \Rightarrow\left\{\begin{array}{c}
2 E=V_{2}+E \\
-2 E=V_{2}-E
\end{array} \Rightarrow\left|V_{2}\right|=E\right.
$$

If the source voltage magnitude $\mathrm{V}_{\mathrm{dc}}$ is fixed at $2 \mathrm{E}$, to produce the required load voltage, the capacitor voltage $\mathrm{V}_{\mathrm{c}}$ must be maintained at $\mathrm{E}$. So the charging and discharging time keeps the capacitor voltage at $\pm \mathrm{E}$. Therefore, to maintain equal charging and discharging times, switching state 2 charge the capacitor in the positive half cycle and switching state 6 discharge the capacitor in negative half cycle [21, 22]. Charging and discharging of capacitors depends on the type of load only, not on the output frequency or switching frequency, the size of the capacitor depends on the type of load.

The sensor less voltage regulating technique is integrated with modulation technique [23-25]. The level shifted Multi carrier switching technique is used as modulation technique [26]. For implementation of five level PWM inverter scheme, four carrier waveforms $(\mathrm{Cr} 1, \mathrm{Cr} 2, \mathrm{Cr} 3$, and $\mathrm{Cr} 4)$ and reference sine wave are used shown in Figure 4.

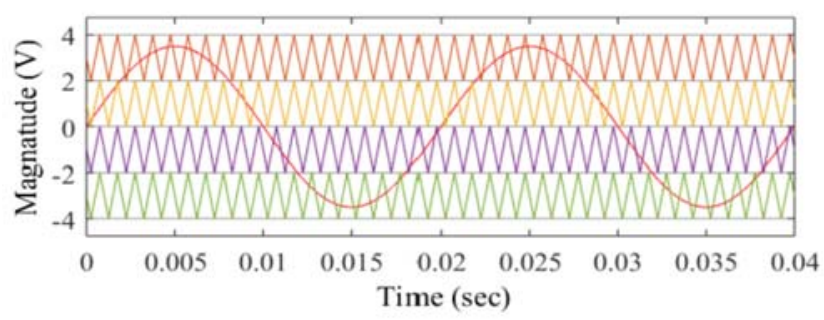

Figure 4. Five-level PWM scheme using four level shifted carrier waves

Hear four triangular signals are vertically shifted for modulating the reference sine wave. This modulation output pulse is associated with the switching states 1, 2, 5, 6 and 8 shown in Table 1 . The algorithms for generating the firing pulses are presented in Figure 5. This proposed algorithm generates the

Three phase PUC5 inverter fed induction motor for renewable energy applications (G. V. V. Nagaraju) 
five level output on PUC5 inverter after setting the capacitor voltage at a correct value without any feedback sensor. The capacitor and output voltages don't depend on the type of the system model (e.g. Average modelling), modulation index, feedback sensors, grid frequency and switching frequency.

It can operate the system voltage to any arbitrary value. The PV source voltage may be flacuvates because of changes in climatic conditions. This sensor less voltage balancing perfectly work with any changes in source voltage. We can change the fundamental frequency as well as induction motor speed, by changing the $\mathrm{V}_{\text {Ref }}$ signal frequency.

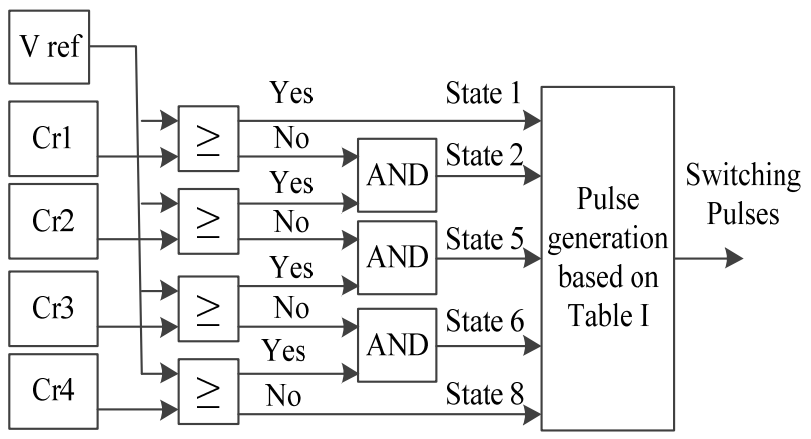

Figure 5. Proposed sensor-less voltage regulating approach integrated into switching technique

Table 1. Switching states, Capacitor charging/discharging states and output voltage of five levels PUC

\begin{tabular}{ccccccc}
\hline State & S1 & S2 & S3 & V output & V out value & Capacitor voltage status \\
\hline 1 & 1 & 0 & 0 & $\mathrm{~V}_{\mathrm{DC}}$ & $+2 E$ & No Effect \\
2 & 1 & 0 & 1 & $\mathrm{~V}_{\mathrm{DC}}-\mathrm{V}_{\mathrm{C}}$ & $+E$ & Charging \\
3 & 1 & 1 & 0 & $\mathrm{~V}_{\mathrm{C}}$ & $+E$ & Discharging \\
4 & 1 & 1 & 1 & 0 & 0 & No Effect \\
5 & 0 & 0 & 0 & 0 & 0 & No Effect \\
6 & 0 & 0 & 1 & $-\mathrm{V}_{\mathrm{C}}$ & $-E$ & Discharging \\
7 & 0 & 1 & 0 & $\mathrm{~V}_{\mathrm{C}}-\mathrm{V}_{\mathrm{DC}}$ & $-E$ & Charging \\
8 & 0 & 1 & 1 & $-\mathrm{V}_{\mathrm{DC}}$ & $-2 E$ & No Effect \\
\hline
\end{tabular}

\section{COMPARISON BETWEEN PUC5 AND OTHER TOPOLOGIES}

This PUC5 topology is separately compared with full bridge, CHB and NPC/T3 converters in terms of component count, switching frequency and voltage rating. Obviously FC inverter has more number of components to control since this topology was not considered. However, NPC and T3 have same principle concept, they are compared in the same subsection.

\subsection{Comparison between single phase PUC and FB inverters}

Full bridge inverter shown in Figure 6(a) is the most common inverter topology in the market because of simple structure. It has one isolated DC source, four switches. However, each switch suffers $2 \mathrm{E}$ volts if $\mathrm{V}_{1}$ would be equal to PUC5 inverter DC source. Based on an equal voltage rating design the switches cost of PUC5 would be lower than full bridge at equal voltage/power rating. However full bridge produces three level output voltage while PUC5 inverter has better THD results with five level voltage with added cost of one capacitor. More ever the quasi-sine wave at the output, reduce the harmonics which would diminish the filter size at least by half ratio and overall size and cost of inverter would be reduced.

\subsection{Comparison between single phase $\mathrm{PUC}$ and $\mathrm{CHB}$}

A five level CHB consists of two full bridge cells connected in series as shown in Figure 6(b). Where as the output voltage is the sum of two cells, so it includes two isolated DC sources of each E volts and eight switches with an identical voltage rating of each E volts. Accordingly, it has exactly the same design as the PUC5 topology as shown in Figure 2(a). These two converters generate five level voltage at the output. So the THD and output filter design would be same. Only the difference between five level CHB and PUC5 is one DC source. Two DC sources of Magnitudes E are used in CHB to generate five level waveform. The main question is that using two DC sources with each E volts is better or using a single DC source with 
2E volts? Normally in renewable energy conversion system only one bus available from the PV or wind farms that should be connected to the inverter. Therefore CHB with more than one isolated DC source require more splitting in the $\mathrm{PV}$ panel or wind turbine into different arrays with separated connections to make more isolated DC buses. Such type configuration requires power balancing between DC sources, particularly during any renewable energy generation level variation caused by environmental factors. However, replacing the existing two level topology with those inverters that have more isolated DC sources would be more difficult due to change the DC side structure. Because of the above discussed merits, PUC5 inverter with single DC source is the best solution.

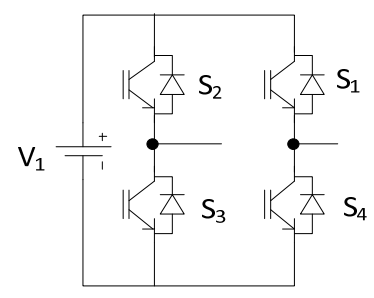

(a)

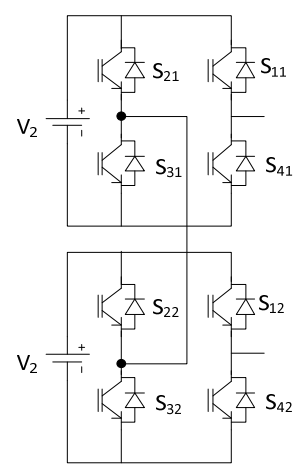

(b)

Figure 6. (a) Full bridge inverter, (b) Five level CHB inverter

\subsection{Comparison between single phase PUC and NPC/T3}

NPC and T3 are the most popular in applications as a three level inverter, while line voltage will generate five levels of output when two legs and one DC source are used in single as shown in Figure 7(a) and 7(b). An NPC contains eight switches and four diodes which is considerably more than PUC5 components. T3 inverter has eight switches as shown in Figure 7(b). Out of eight S1, S2, S3 and S4 are required to bear the whole $\mathrm{DC}$ bus voltage $2 \mathrm{E}$ volts. This unequal voltage rating switches is the main disadvantage in T3 inverter. Moreover, both NPC and T3 inverters require two capacitors to split the single DC source voltage, it is one extra capacitor than PUC5 inverter capacitors. Eventually the voltage balancing also difficult in NPC/T3 when compared with PUC5.

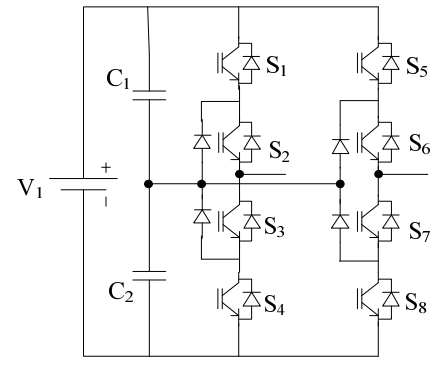

(a)

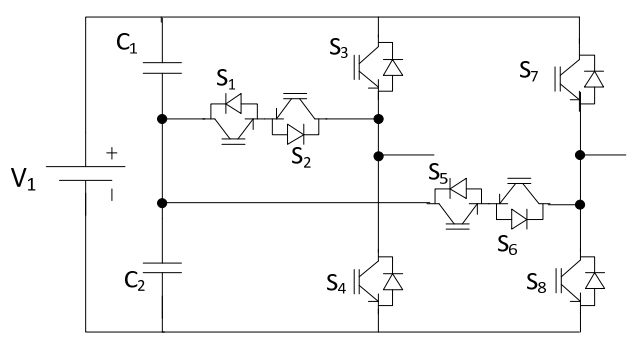

(b)

Figure 7. (a) Five level NPC inverter, (b) Five level T3 inverter

\subsection{Comparison between three phase PUC and NPC/T3}

In both NPC and T3 inverters only one leg added to the single phase two leg structure shown in Figure 7 (a) and (b) and another advantage with three phase NPC is only one DC source and two capacitors are required for all three phases. But the voltage balancing is much more complex in these two inverters compared to PUC5. So many methods have been appeared in literature to balance the capacitor voltage at DC source such as linear PI regulator, nonlinear controllers and zero component injection. The simplest 
controller used in NPC or T3 is space vector controller, this can be integrated into space vector modulation technique. However, in three phase PUC5 inverter simple sensor less voltage balancing is integrated into very simple modulation that is PWM modulation to regulate the capacitor voltage. Furthermore, the three phase NPC/T3 inverter produces three level waveform in each phase, further increase in levels require an extreme number of switches and isolated sources. On the other hand three phase PUC5 produces up to nine levels in each phase by using the same components used in three level PUC.

\subsection{Comparison between three phase PUC and CHB}

Three phase five level CHB consists of two sources and six switches in each phase that is total six sources and 24 switches. Only the difference is three isolated switches which will increase the manufacturing cost and size of the inverter. Remaining all characteristics, including voltage rating, voltage level, applications and THD value are same in both CHB and PUC inverters.

Table 2 shows the component count comparison for single phase five level inverters. All above comparisons proved that the PUC inverter is the best topology for replacing existing two, three and five level inverters on the market.

Table 2. Component count comparison for single phase five level inverters

\begin{tabular}{cccccc}
\hline Inverter type & DC Sources & Capacitors & Diodes & Switches & Total components \\
\hline CHB & 2 & 0 & 0 & 8 & 10 \\
NPC without voltage control & 4 & 0 & 6 & 8 & 18 \\
FC & 1 & 3 & 0 & 8 & 12 \\
PUC5 & 1 & 1 & 0 & 6 & 8 \\
\hline
\end{tabular}

\section{SIMULATION RESULTS AND DISCUSSION}

Proposed a three phase five level PUC5 inverter is built in Matlab/Simulink with the given parameters. The performance is tested with sudden load change at $0.5 \mathrm{Sec}$. It was simulated in Matlab/Simulink software and the results shows the performance of three phase PUC5 inverters fed induction motor. It is simulated for one second. The test system simulation parameters are listed in Table 3 . Figure 8 shows the three-phase line to line voltage output of inverter with seven levels. Figure 9 shows capacitor voltage which is zero at starting and increasing up to 220 volts and then it is constant, maintained at half of the $V_{D C}$ throughout the simulation. Figure 10 shows the phase to ground voltage output with the five levels.

Figure 11 shows the three phase inverter load current which is almost pure sine wave, Figure 12 shows the load current in B phase, which is very high at starting because of induction motor load after 0.1 seconds it settles to normal values, Figure 13 shows the THD spectrum of load current analyzed by FFT analysis. It is done at $0.5 \mathrm{sec}$ as starting time and evaluated for three cycles. It shows the THD value $20.23 \%$. Similarly, current wave showing the THD value $1.87 \%$. Which is showing very good performance. Figure 14 shows the speed of the drive, which is almost constant, at $0.5 \mathrm{Sec}$ sudden load change is applied.

Table 3. Simulation parameters

\begin{tabular}{cc}
\hline Parameter & Value \\
\hline $\mathrm{V}_{\mathrm{DC}}$ & $440 \mathrm{~V}$ \\
$\mathrm{C}$ & $0.015 \mathrm{~F}$ \\
Inverter fundamental frequency & $50 \mathrm{~Hz}$ \\
Squirrel Cage Motor & $460 \mathrm{~V}, 50 \mathrm{~Hz}, 3730 \mathrm{~W}]$ \\
Carrier frequency & $5 \mathrm{kHz}$ \\
$\mathrm{V}_{\text {Ref } \max }$ & $1.75 \mathrm{~V}$ \\
\hline
\end{tabular}

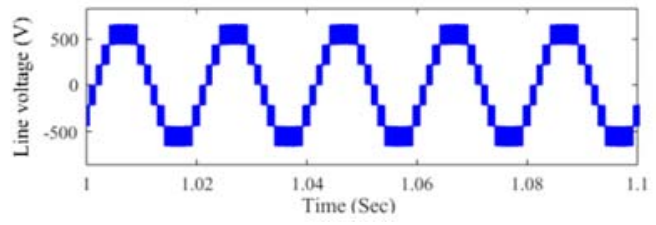

Figure 8. Three-phase line to line voltage output of inverter with seven levels

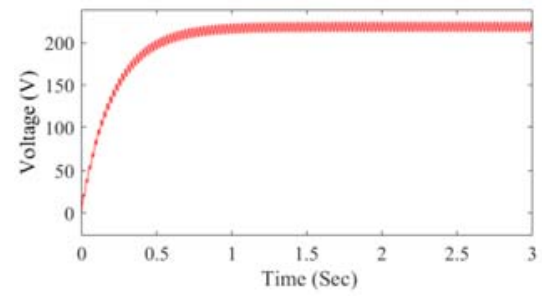

Figure 9. Voltage across the capacitor $\left(\mathrm{V}_{\mathrm{c}}\right)$

Int J Pow Elec \& Dri Syst Vol. 11, No. 1, Mar 2020 : 1 -9 


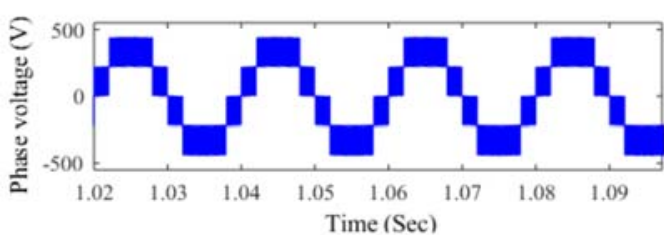

Figure 10. Phase to ground voltage output

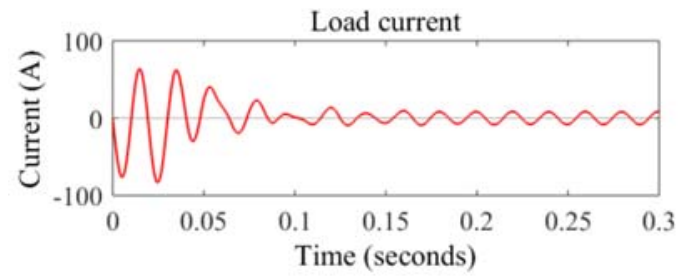

Figure 12. Load current in phase B

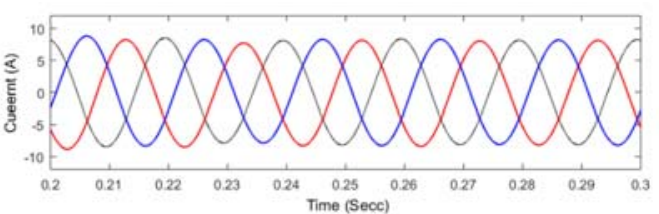

Figure 11. Three phase load current

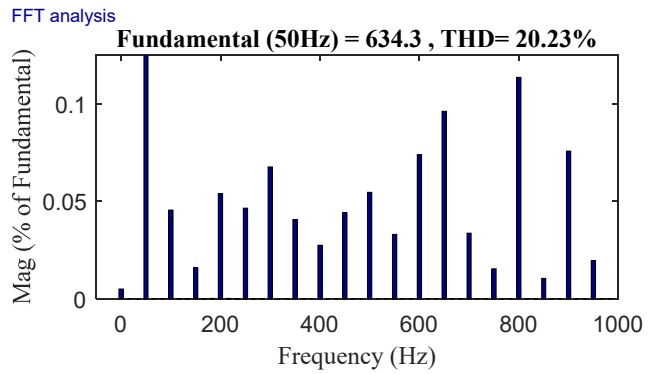

Figure 14. THD spectrum of line voltage

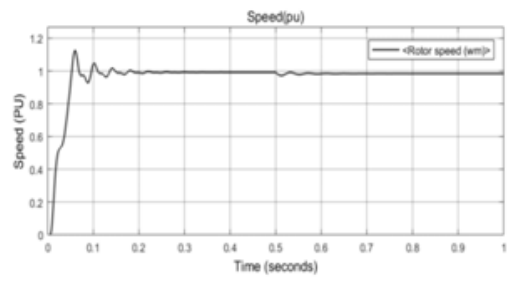

Figure 13. Speed of the induction motor $(\mathrm{Pu})$

\section{CONCLUSION}

In this paper sensor less voltage controlling technic is suggested for PUC converter fed induction motor with a PV source along with boot converter and a single capacitor in each phase with minimum number components. Compared to all other existing systems, it requires only six switches in each phase and does not require any sensor which will reduce the cost and complexity of the system. All the demerits of neutral clamped inverters and flying capacitor inverters are eliminated in the PUC5 inverter. This system is simulated in Matlab/Simulinl, the results showing good dynamic performance and power quality is also improved. It has less weight because of less components and more suitable for moving electric vehicles. By varying the $\mathrm{V}_{\text {ref }}$ sine wave signal frequency, we can change the speed of the motor. This inverter is best suitable for interface the renewable energy source with induction motor.

\section{REFERENCES}

[1] Ounejjar, Youssef, Kamal Al-Haddad, and Luc-Andre GreFgoire. "Packed U cells multilevel converter topology: theoretical study and experimental validation" IEEE Transactions on Industrial Electronics, Vol. 58, No. 4, pp. 1294-1306, 2011.

[2] Babadi, Adel Nazemi, et al. "Modified Multilevel Inverters with Reduced Structures Based on PackedU-Cell" IEEE Journal of Emerging and Selected Topics in Power Electronics, Vol. 6, No. 2, pp. 874-887, 2018.

[3] Zid, Alaeddine Ben, Abdlekarim Aouiti, and Faouzi Bacha. "Study and simulation of three-phase seven-level packed U cells inverter" 2017 18th International Conference on Sciences and Techniques of Automatic Control and Computer Engineering (STA). IEEE, 2017.

[4] Sathik, M. Jagabar, et al. "An Improved Seven-Level PUC Inverter Topology with Voltage Boosting" IEEE Transactions on Circuits and Systems II: Express Briefs, 2019.

[5] Abarzadeh, Mostafa, Hani Vahedi, and Kamal Al-Haddad. "Fast sensor-less voltage balancing and capacitor size reduction in PUC5 converter using novel modulation method" IEEE Transactions on Industrial Informatics (2019).

Three phase PUC5 inverter fed induction motor for renewable energy applications (G. V. V. Nagaraju) 
[6] Najafi, Ehsan, and Abdul Halim Mohamed Yatim. "Design and implementation of a new multilevel inverter topology" IEEE transactions on industrial electronics, Vol. 59, No. 11, pp. 4148-4154, 2011.

[7] Vahedi, Hani, and Kamal Al-Haddad. "Real-time implementation of a seven-level packed U-cell inverter with a low-switching-frequency voltage regulator" IEEE Transactions on Power Electronics, Vol. 31, No. 8, pp. 5967-5973, 2016.

[8] Metri, Julie I., et al. "Real-time implementation of model-predictive control on seven-level packed U-cell inverter" IEEE Transactions on Industrial Electronics, Vol. 63, No. 7, pp. 4180-4186, 2016.

[9] Metri, Julie, et al. "Model predictive control for the packed U-Cells 7-level grid connected inverter" 2016 IEEE International Conference on Industrial Technology (ICIT). IEEE, 2016.

[10] Qashqai, Pouria, et al. "A review on multilevel converter topologies for electric transportation applications" 2015 IEEE Vehicle Power and Propulsion Conference (VPPC). IEEE, 2015.

[11] Arunprasath, R., et al. "Performance Evaluation of SEPIC Based Single-Phase Seven-Level Inverter for Renewable Applications" International Journal of Renewable Energy Research (IJRER), Vol. 9, No. 2, pp. 704-711, 2019.

[12] Reddy, Ch Rami, and K. Harinadha Reddy. "A New Passive Islanding Detection Technique for Integrated Distributed Generation System Using Rate of Change of Regulator Voltage Over Reactive Power at Balanced Islanding” Journal of Electrical Engineering \& Technology, Vol. 14, No. 2, pp. 527-534, 2019.

[13] Reddy, Ch Rami, and K. Harinadha Reddy. "Passive Islanding Detection Technique for Integrated Distributed Generation at Zero Power Balanced Islanding" International Journal of Integrated Engineering, Vol. 11, No. 6, pp. 126-137, 2019.

[14] Reddy, Ch, and K. Harinadha Reddy. "Islanding detection for inverter based distributed generation with Low frequency current harmonic injection through Q controller and ROCOF analysis" Journal of electrical systems, Vol 14, No. 2, 2018.

[15] CH, Rami Reddy, and K. Harinadha Reddy. "Islanding Detection Techniques for Grid Integrated DG-A Review" International Journal of Renewable Energy Research (IJRER), Vol 9, No. 2, pp. 960-977, 2019.

[16] Azeem, Abdul, et al. "Performance of Five Phase PUC Inverter Fed Five Phase Induction Motor Drive Under Different Triangular Carrier PWM Schemes" IECON 2018-44th Annual Conference of the IEEE Industrial Electronics Society. IEEE, 2018.

[17] Sepahvand, Hossein, Jingsheng Liao, and Mehdi Ferdowsi. "Investigation on capacitor voltage regulation in cascaded H-bridge multilevel converters with fundamental frequency switching" IEEE Transactions on industrial electronics, Vol. 58, No. 11, pp. 5102-5111, 2011.

[18] Vahedi, Hani, and Kamal Al-Haddad. "Single-DC-source five-level CHB inverter with sensor-less voltage balancing" IECON 2015-41st Annual Conference of the IEEE Industrial Electronics Society. IEEE, 2015.

[19] Nagaraju, G. V. V., G. Sambasiva Rao, and Ch Rami Reddy. "Sensor less voltage control of CHB multilevel inverter fed three phase induction motor with one dc source per each phase" International Journal of Pure and Applied Mathematics 120.06 (2018): 4079-4097.

[20] Vahedi, Hani, and Kamal Al-Haddad. "PUC5 inverter-a promising topology for single-phase and three-phase applications" IECON 2016-42nd Annual Conference of the IEEE Industrial Electronics Society. IEEE, 2016.

[21] Ajesh, P. S., Beena M. Varghese, and Annie P. Oommen. "Performance analysis of cascadable U-cell multi level inverter" 2017 International Conference on Technological Advancements in Power and Energy (TAP Energy). IEEE, 2017.

[22] Babaie, Mohammad, et al. "Design of an Artificial Neural Network Control Based on Levenberg-Marquart Algorithm for Grid-Connected Packed U-Cell Inverter"

[23] Rao, G. Sambasiva, and K. Chandra Sekhar. "A novel five-level SPWM Inverter system for dual-fed induction motor drive" 2012 IEEE International Conference on Advanced Communication Control and Computing Technologies (ICACCCT). IEEE, 2012.

[24] Rao, G. Sambasiva, and K. Chandra Sekhar. "A sophisticated Space Vector Pulse Width Modulation Signal Generation for Nine-Level Inverter system for Dual-Fed Induction Motor Drive" The International Congress for global Science and Technology (ICGST). Vol. 7. No. 14. 2012.

[25] Rao, G. Sambasiva, and K. Chandra Sekhar. "A Refined Space Vector PWM Signal Generation for Multilevel Inverters" ACEEE Int. J. on Electrical and Power Engineering, Vol 2, No, 02, pp. 47-55, 2011.

[26] Vahedi, Hani, et al. "Cascaded multilevel inverter with multicarrier PWM technique and voltage balancing feature" 2014 IEEE 23rd International Symposium on Industrial Electronics (ISIE). IEEE, 2014.

Int J Pow Elec \& Dri Syst Vol. 11, No. 1, Mar 2020 : 1 - 9 


\section{BIOGRAPHIES OF AUTHORS}

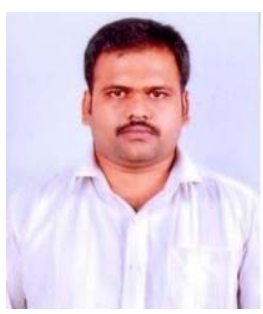

V V Nagaraju Goriparthi received his B. Tech degree in Electrical and Electronics Engineering from JNTU, Hyderabad, India, in 2008 and M. Tech with power system-high voltage from JNTUK, Kakinada, India in 2013. He is pursuing Ph.D in multilevel inverter fed induction motors at Acharya Nagarjuna University, Guntur, India. He is a member of the International Association of Engineers.

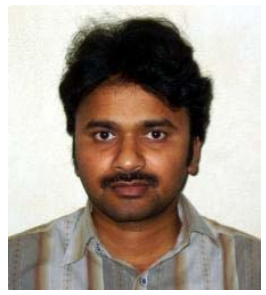

Dr. Gudapati Sambasiva Rao received B.E. degree in Electrical \& Electronics Engg., M.E. degree in Power Electronics \& Industrial Drives and his doctorate in industrial drives. Since 2006, he has been with R.V.R \& J. C. College of engineering, Guntur-522019, India. His research interests are Power Electronics, Electrical Drives, FACTS controllers, Power Quality Improvement. 